\title{
Clinical Considerations for the Association between Vascular Damage and Chronic Kidney Disease
}

\author{
Hirofumi Tomiyama Akira Yamashina \\ Department of Cardiology, Tokyo Medical University, Tokyo, Japan
}

\section{Key Words}

Chronic kidney disease - Cardiovascular disease - Vascular damage - Intima-media thickness . Coronary artery calcium score

\begin{abstract}
Chronic kidney disease (CKD) is an independent risk factor for cardiovascular disease. Recently, noninvasive and simple morphological and functional methods have been introduced to assess atherosclerotic vascular damage. This review describes the association of CKD with vascular damage as assessed by these methods. Carotid intima-media thickness (IMT) and coronary artery calcium score (CACS) are morphological parameters of vascular damage, and an ankle-brachial index ( $A B I)<0.90$ suggests the presence of peripheral arterial disease (i.e., it represents advanced atherosclerosis). Several prospective studies have demonstrated that CKD is a risk factor for an increased IMT, an increased CACS and a decreased ABI. While it has not been clarified whether measuring the IMT or CACS might be useful to predict the progression of renal function decline, a reduced $A B I$ has been demonstrated as a predictor of accelerated renal function decline. On the other hand, pulse wave velocity (PWV) is a marker of arterial stiffness rather than atherosclerosis, reflecting functional abnormalities caused by vascular damage, and moderate-to-severe CKD may be a risk factor for the progression of arterial stiffness. The measurement of functional markers, especially of PWV or pulse pressure, has been demonstrated to be useful to predict the rate of progression of renal function decline. Thus, renal dysfunction and atherogenic states may be components of a vicious cycle, and vascular function abnormalities associated with atherosclerosis may accelerate this cycle. As the next step, we propose to examine whether improvement of vascular function abnormalities can interrupt this vicious cycle.


Tomiyama and Yamashina: Clinical Considerations for the Association between

Vascular Damage and Chronic Kidney Disease

\section{Introduction}

In addition to conventional risk factors for cardiovascular (CV) disease, chronic kidney disease (CKD) is also an independent risk factor [1,2]. Combined disorders of the heart and kidney are common and have been referred to as the cardiorenal syndrome [3, 4]. Atherosclerotic vascular disorder is one of the common pathways for heart failure and kidney disease $[3,4]$. Clinically, atherosclerotic vascular damage is assessed by morphological and functional approaches. Those parameters of atherosclerotic vascular damage are used as predictors of future CV events [5], and they are a rather useful tool for the prevention and management of $\mathrm{CV}$ disease. On the other hand, the usefulness of the parameters of vascular damage for the management of renal dysfunction has not yet been fully clarified.

This review summarizes the methodologies used for the morphological and functional assessment of vascular damage in clinical settings and describes the pathophysiological basis for the association between vascular damage and renal dysfunction.

\section{Methodologies to Assess Vascular Damage}

\section{Morphological Assessments}

Carotid Ultrasound

Carotid intima-media thickness (IMT) is measured by B-mode ultrasound, in which the distance from the intimal to the adventitial layer is measured as the width of the typical double line of the arterial wall. Usually, IMT is measured in the common carotid artery [6]. IMT increases with the progression of atherosclerosis, and in cases with advanced atherosclerosis, atherosclerotic plaques can be detected by carotid ultrasonography (fig. 1). Assessing IMT, an increase of which is an independent risk factor for future CV events, has been demonstrated to show acceptable reproducibility $[6,7]$. While the methodological consensus for standardization has been obtained and reference values have been reported [8], experienced sonographers are required for the measurement $[6,7]$.

\section{Coronary Artery Calcium Score}

Calcification of coronary arteries is strictly associated with the process of atherosclerotic plaque formation; therefore, the presence of calcific deposits in the coronary arteries is considered to be pathognomonic of coronary atherosclerosis. Electron beam or multislice computed tomography is used to measure the coronary artery calcium score (CACS). Using images of 3-mm slice thickness, CACS is calculated as the area of calcification per coronary segment. CACS is commonly classified into four categories: $0,1-99,100-399$, and $\geq 400$ [9]. Recently, the Multi-Ethnic Study of Atherosclerosis (MESA) has reported that CACS allows a superior discrimination and risk reclassification as compared to other risk markers [10].

\section{Functional Assessments}

Endothelial Function

Flow-Mediated Vasodilatation. Flow-mediated vasodilatation (FMD) is calculated as the percent change of the diameter of the brachial artery (i.e., the diameter before reactive hyperemia vs. the maximum dilatation induced by reactive hyperemia) $[5,11]$. Usually, reactive hyperemia is induced by compression of the forearm by inflation of a pressure cuff to $200-250 \mathrm{~mm} \mathrm{Hg}$ for $5 \mathrm{~min}$. The limitation of this method is that it is operator-dependent, although recently, semiautomated devices have been introduced to overcome this disadvantage (fig. 2). 
Tomiyama and Yamashina: Clinical Considerations for the Association between Vascular Damage and Chronic Kidney Disease

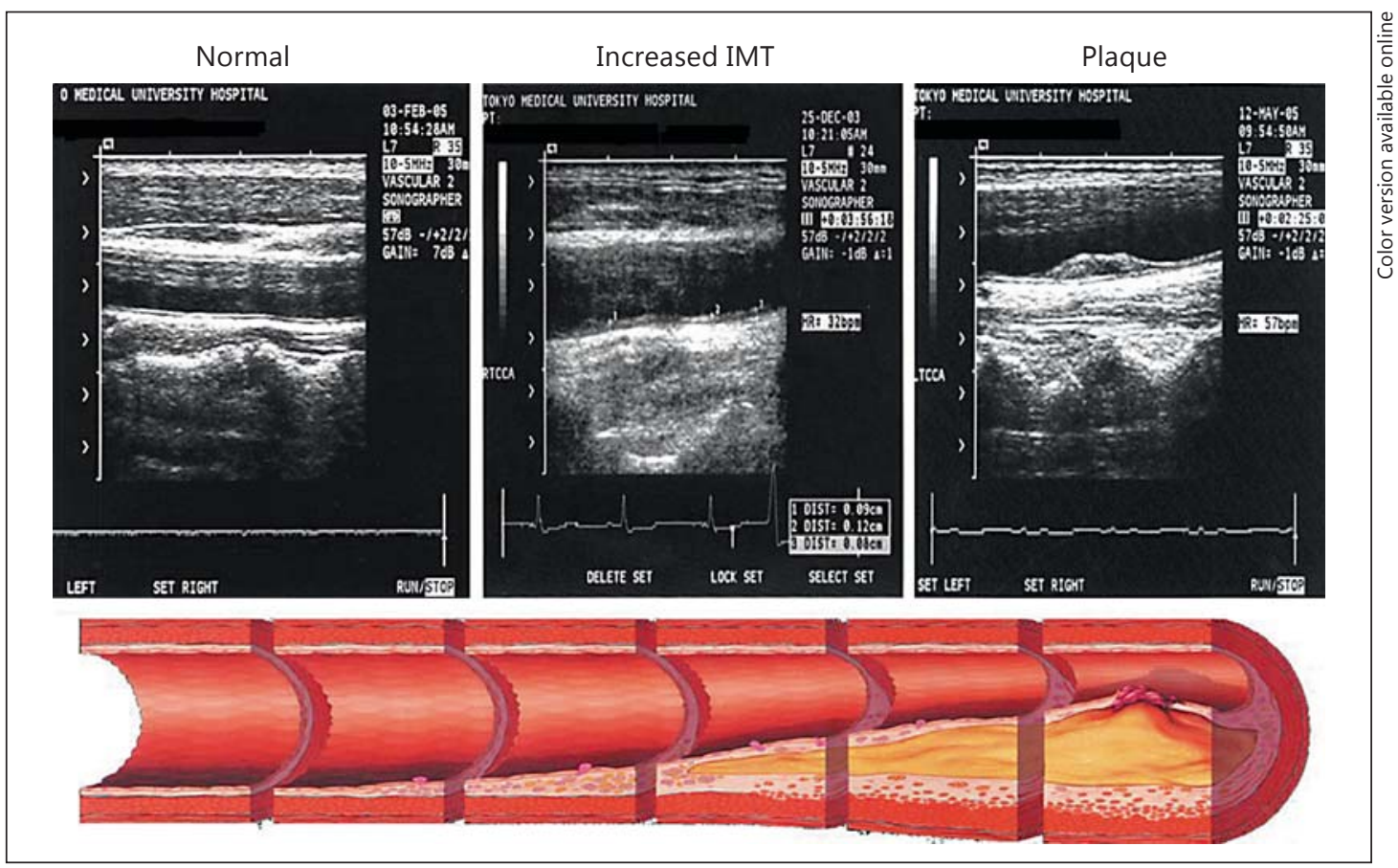

Fig. 1. Carotid ultrasound images with the progression of carotid atherosclerosis.
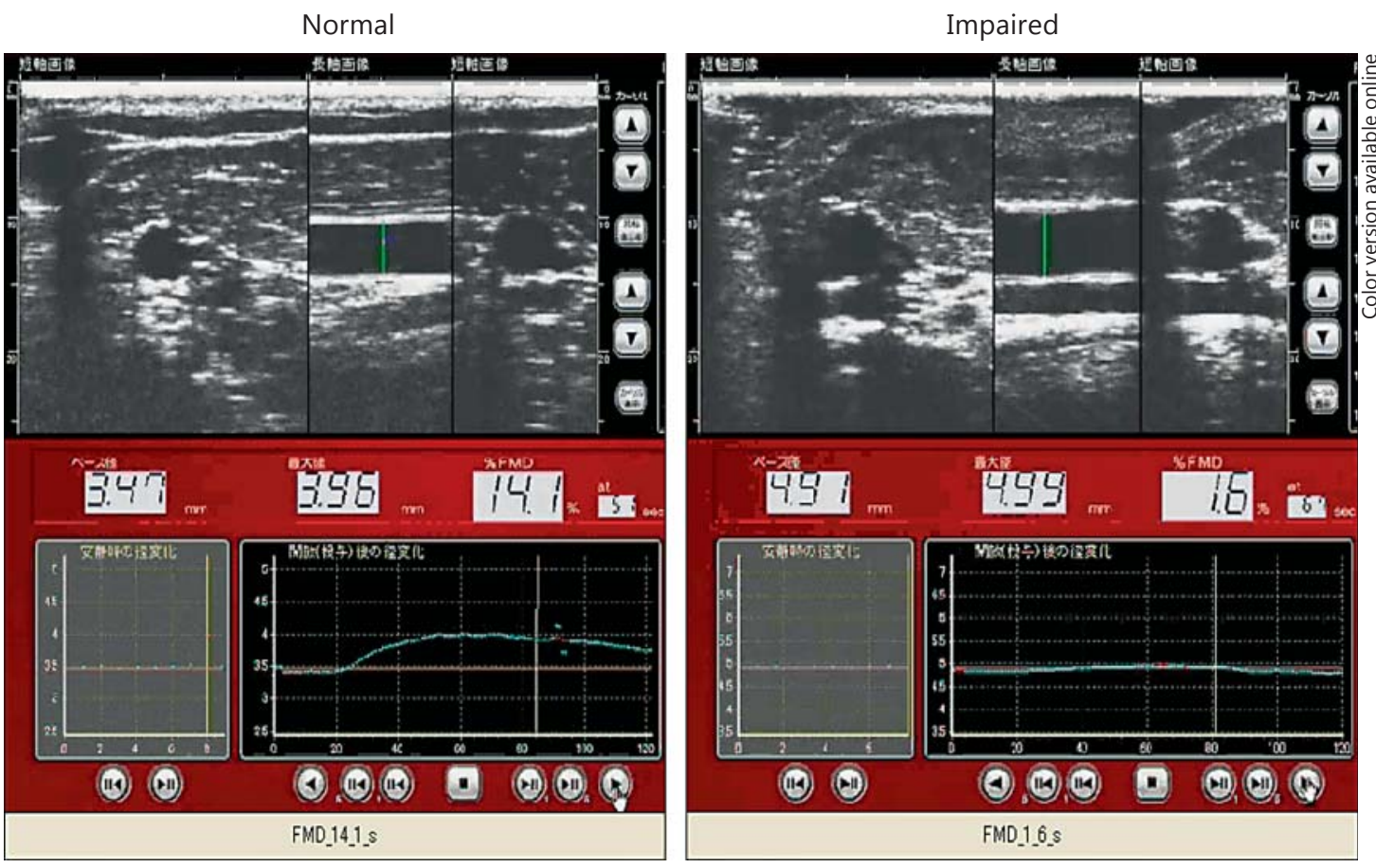

Fig. 2. Results of FMD measurement under normal and disease (impaired) conditions. 


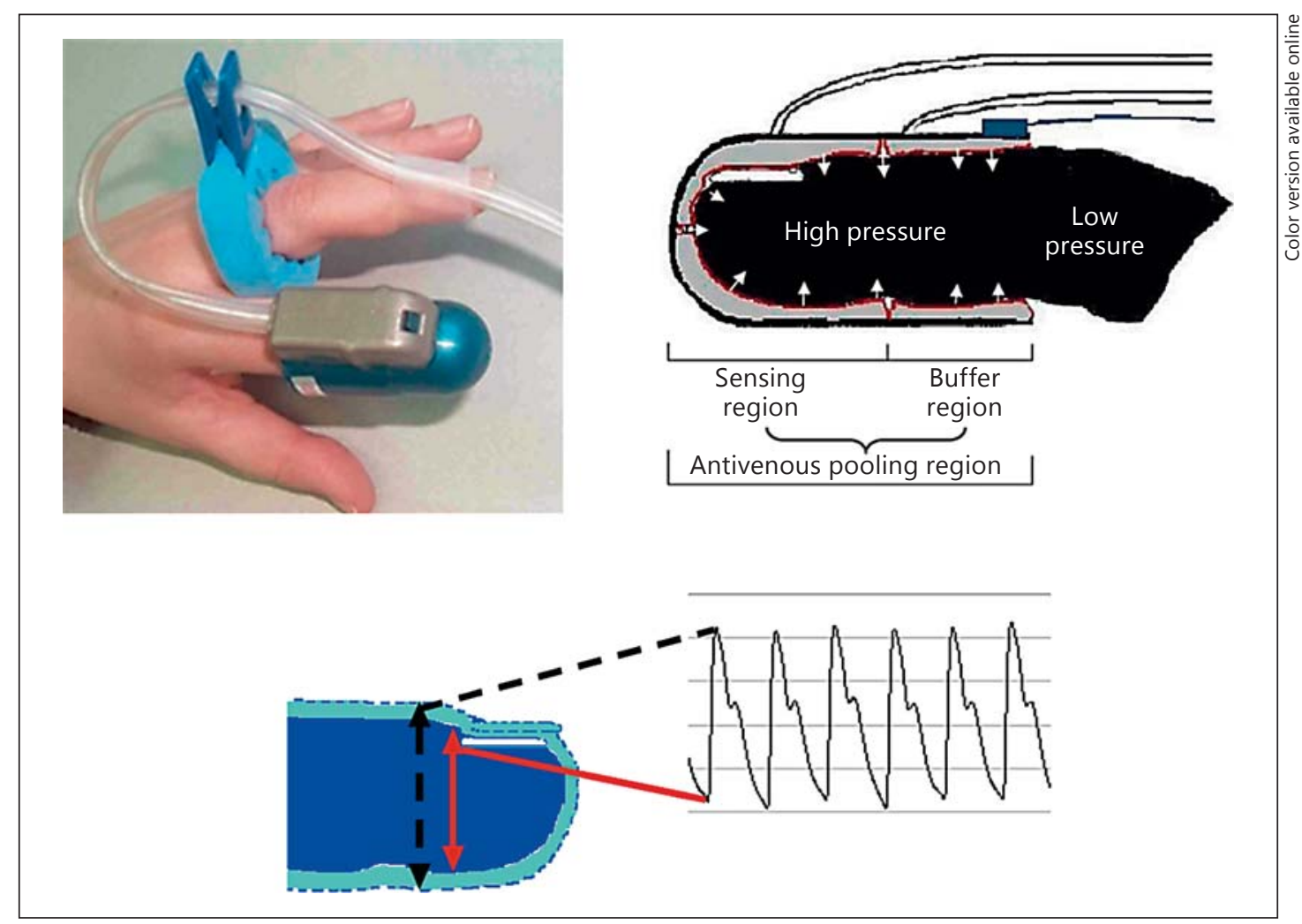

Fig. 3. Description of RH-PAT.

Reactive Hyperemia Index Measured by Peripheral Arterial Tonometry. The reactive hyperemia index measured by peripheral arterial tonometry (RH-PAT) is based on the noninvasive measurement of changes in the pulsatile volume at the fingertip (before and after reactive hyperemia) by PAT (fig. 3) [11]. The procedure for inducing reactive hyperemia is the same as that used for the measurement of FMD. PAT probes are placed on the index finger of each arm, and the post- to preocclusion ratio is calculated. The RH-PAT signals are corrected for the signals in the contralateral arm. FMD reflects endothelial function in the conduit arteries, while RH-PAT reflects endothelial function in the peripheral resistance arteries, and the two parameters have not been demonstrated to show a close association with each other $[5,11]$. However, while the two parameters may not be interchangeable markers, several prospective studies have demonstrated that they are independently useful for predicting future CV events $[5,7,11]$. Measurements of both show acceptable reproducibility, although that of FMD is more operator-dependent. At present, some methodological differences exist in the measurement of FMD among institutions (e.g., in the placement of the pressure cuff above vs. below the elbow, duration of cuff occlusion, method used to determine the vascular diameter, and definition of maximal dilatation of the brachial artery), and there are no reference values. On the other hand, RH-PAT is measured by a uniform method, although reference values have not been established for this parameter either.

Pulse Wave Velocity

Pulse wave velocity (PWV) reflects segmental arterial elasticity [5, 7]. Contraction of the left ventricle generates a pulse wave, which is propagated throughout the arterial tree. PWV 
Tomiyama and Yamashina: Clinical Considerations for the Association between

Vascular Damage and Chronic Kidney Disease

is calculated as the distance traveled by the pulse wave divided by the time taken by the wave to travel the distance: $\mathrm{PWV}=\Delta \mathrm{L} / \Delta \mathrm{T}$, where $\Delta \mathrm{Lm}$ is the distance between the two sites of pulse wave recording (in meters) and $\Delta \mathrm{T}$ is the time delay in the appearance of the pulse wave from the proximal to the distal site of the recording (in seconds). The Moens-Korteweg equation states that the PWV is proportional to the square root of the incremental elastic modulus of the vessel wall, given a constant ratio of the wall thickness to the vessel radius and blood density. Therefore, increased arterial rigidity and arterial wall thickness act to increase the PWV. PWV can be measured in any arterial segment between two pulse-wave palpable regions.

Carotid-Femoral PWV. Carotid-femoral PWV (cfPWV) is the most commonly used noninvasive method for determining the PWV and is considered the gold standard [5, 10, 12]. Usually, it is measured using the 'foot-to-foot' velocity method $[10,12]$ and recorded transcutaneously at the right common carotid artery and right femoral artery, and the time delay is measured between the feet of the two waveforms. While several methodological differences existed in the measurement of the cfPWV (e.g., in the method used to determine the foot of a waveform or in the calculation of the path length), now, a standardized method has been established [13].

Brachial-Ankle PWV. Brachial-ankle PWV (baPWV) is measured using a volume-plethysmographic apparatus. Since baPWV only involves wrapping a pressure cuff around the four limbs for its measurement, it is easier to measure than cfPWV, and the measurement is also well-standardized. The brachial and posterior tibial arterial pressure waveforms are recorded by a plethysmographic sensor. baPWV reflects the stiffness of the large- to middle-sized arteries $[5,12]$. The method has been primarily used in Asian populations. In the measurement of baPWV, the ankle-brachial pressure index (ABI) is simultaneously obtained, and when the $\mathrm{ABI}$ is $<0.95$, the accuracy of baPWV is diminished [14]. Meta-analyses have already confirmed that not only an increased cfPWV, but also an increased baPWV, is an independent risk factor for $\mathrm{CV}$ events and that there is a significant positive relation between the baPWV and cfPWV $(r=0.73)$ [15]. The standard value of cfPWV is $10 \mathrm{~m} / \mathrm{s}$ and that of baPWV is $18 \mathrm{~m} / \mathrm{s}[5,11]$.

\section{Wave Reflections/Central Hemodynamics}

Cardiac contraction generates a pressure pulse wave, which propagates from the heart to the periphery $[5,9,16]$. On the other hand, in the arterial tree, the arteries branch and taper as they reach the periphery, which is associated with an increase in the arterial resistance. A reflected pressure pulse wave (from the periphery towards the heart) occurs at sites of abrupt increase of arterial resistance. Then, an interaction between the forward and reflected pressure pulse waves occurs in the arterial tree. Under physiological conditions, this interaction is observed at a distal site of the arterial tree; therefore, blood pressure is lower at the level of the kidney than at the level of the brachial artery. Under the condition of increased arterial stiffness, on the other hand, the travelling speed of the pressure pulse wave is increased and the interaction between the forward and reflected pulse wave is observed at a more proximal site of the arterial tree (i.e., the aorta). Pressure wave analysis is conducted at the carotid, radial or brachial artery. Since the radial bone is backboned, the radial arterial pressure wave can be easily recorded. Therefore, recently, radial pressure wave analysis has become a common approach. The AtCor and the OMRON devices are popularly used for radial pressure wave analysis (fig. 4) [5, 12, 16]. The AtCor device estimates the central systolic blood pressure derived by the general transfer function of the radial pressure wave, and the OMRON device estimates the central systolic blood pressure derived by the regression equation from the directly measured late systolic shoulder of the radial pressure waveform. Estimation of the central systolic blood pressure based on the late systolic shoulder of the radial pressure wave provides comparable accuracy to that of the validated general transfer 


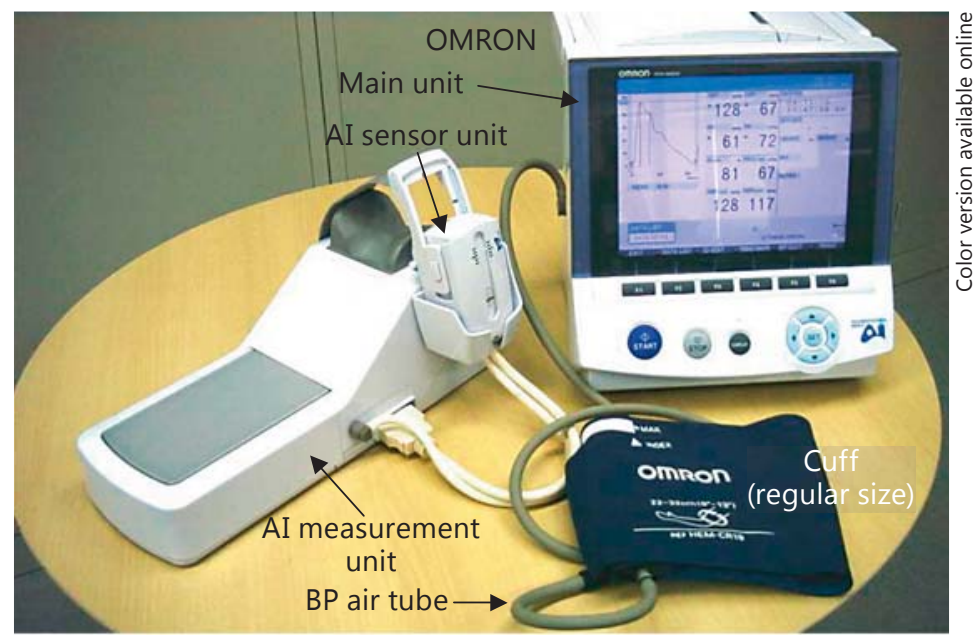

Fig. 4. Devices used for radial pressure waveform analysis.

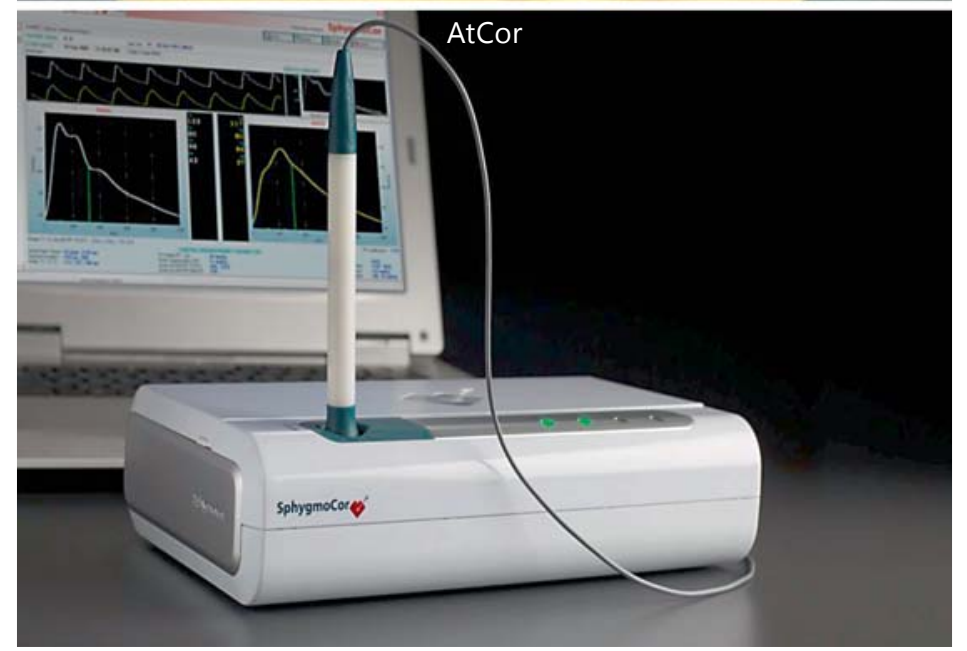

function [17]. However, standard values of pressure wave analyses/central hemodynamics have not yet been clearly established, and an international project to determine the reference values of the central hemodynamic indices is ongoing.

\section{Ankle-Brachial Index}

Normally, systolic blood pressure is higher in the lower extremities than in the arms. The $\mathrm{ABI}$ is the ratio of the ankle-to-brachial systolic pressure. The standard mode of measurement requires a (hand-held) continuous-wave Doppler device and a manual blood pressure cuff [18]. This method allows measuring the systolic blood pressures of the posterior tibial and dorsalis pedis arteries. Recently, an oscillometric device has become available to measure the ABI $[5,19]$. This method is easier as compared to the method using the Doppler device because the former only involves wrapping of a pressure cuff around the four limbs. The ABI measured by the oscillometric method has an acceptable accuracy (fig. 5) [19]. An ABI $<0.90$ reflects the presence of peripheral arterial disease. The sensitivity and specificity of an ABI $<0.90$ for $>50 \%$ stenosis in the lower limb arteries are 90 and $95 \%$ [20], respectively. The meta-analysis demonstrated that not only an $\mathrm{ABI}<0.90$, but also an $\mathrm{ABI}>1.40$ is an independent risk factor for future CV events [21]. 
Tomiyama and Yamashina: Clinical Considerations for the Association between Vascular Damage and Chronic Kidney Disease

Fig. 5. Correlation between the ABI value obtained using a Doppler device and that obtained using an oscillometric device in the posterior tibial artery (a) and the dorsalis pedis artery (b).

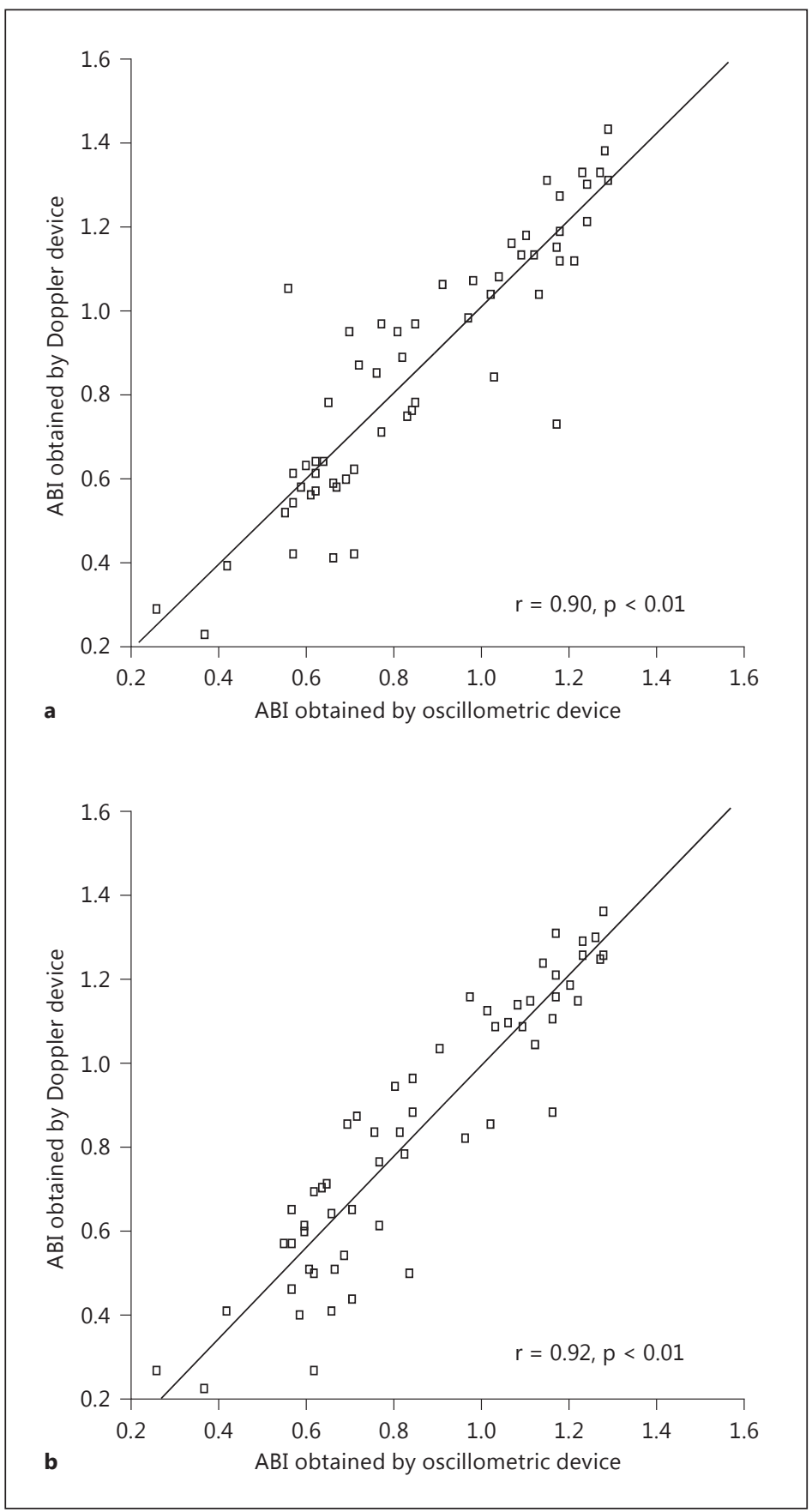

\section{Vascular Damage and Renal Dysfunction}

Effect of CKD on the Progression of Vascular Damage as Assessed from the Morphological and Functional Aspects

Recent meta-analyses have confirmed that CKD is an independent risk factor for clinical outcomes such as mortality and dialysis/kidney transplantation [1, 2]. Anemia, sympathetic nerve activation, oxidative stress/inflammation, endothelial dysfunction, coagulation disorders, abnormal mineral metabolisms, and/or uremic toxins are thought to be additional risk factors for atherosclerotic vascular damage in patients with CKD [22]. 
Tomiyama and Yamashina: Clinical Considerations for the Association between

Vascular Damage and Chronic Kidney Disease

\section{IMT and CACS}

Carotid IMT has been reported to be increased even in subjects with early-stage CKD [23], and this association is especially pronounced in subjects with hypertension [24]. Desbien et al. [25] conducted a 2-year prospective study to examine the association between CKD of different severities and the carotid IMT in a community cohort $(n=3,364)$ and demonstrated that decreased renal function was associated with accelerated increase of the IMT. Furthermore, Yilmaz et al. [26] reported that kidney transplantation was associated with a decrease of the IMT within 90 days of the transplantation, and this decrease was associated with the improvement of the glomerular filtration rate (GFR). Thus, even early-stage CKD may affect the rate of increase of the carotid IMT. CACS can be assessed by electron-beam or multislice computed tomography. The Chronic Renal Insufficiency Cohort (CRIC) study [27] reported the existence of a significant relationship between the estimated GFR (eGFR) and CACS: the lower the eGFR, the higher the CACS. Among prospective studies, the MESA ( $\mathrm{n}=$ 2,795 ) demonstrated that the incidence of coronary artery calcification (CACS $>0$ ) was higher in subjects with eGFR values of $30-59 \mathrm{ml} / \mathrm{min} / 1.73 \mathrm{~m}^{2}(27 \%)$ than in those with eGFR values of $>90 \mathrm{ml} / \mathrm{min} / 1.73 \mathrm{~m}^{2}(12 \%)$ during a 2.4-year follow-up period [28]. The Spokane Heart Study $(n=883)$ also reported similar findings over a 6-year follow-up period [29].

\section{Endothelial Function}

Endothelial dysfunction is an early-stage abnormality in atherosclerotic vascular damage $[5,10]$, and several cross-sectional studies have demonstrated the existence of endothelial dysfunction in patients with CKD. Yilmaz et al. [30] reported that endothelial dysfunction was observed even in cases with early-stage CKD; however, Lilitkarntakul et al. [31] reported that endothelial dysfunction was significant only in subjects with stage 5 CKD. Hypertension and diabetes mellitus, both of which can cause endothelial dysfunction, are common disorders in CKD, and they might be confounding factors when evaluating the association of CKD with endothelial dysfunction [32]. Thus, a further prospective study is proposed to examine whether early-stage CKD might be a risk factor for the progression of endothelial dysfunction.

PWV and Wave Reflection/Central Hemodynamics

Several cross-sectional studies have reported the existence of a significant association between accelerated GFR decline and increased arterial stiffness [33, 34]. Previously, however, we reported, based on a 5.6-year follow-up study $(n=2,053)$, that early CKD was not a risk factor for arterial stiffening as assessed by the baPWV [35]. Tholen et al. [36] reported that loss of renal function had no significant impact on the increase of cfPWV during a 1-year follow-up period in subjects with mild CKD ( $\mathrm{n}=70$, mean eGFR $52 \mathrm{ml} / \mathrm{min} / 1.73 \mathrm{~m}^{2}$ ). On the other hand, Benetos et al. [37] demonstrated that high serum creatinine ( $>1.0 \mathrm{mg} / \mathrm{dl})$ was associated with an accelerated increase of cfPWV over a 6-year observation period in subjects with treated hypertension $(n=483)$. Furthermore, in subjects under maintenance hemodialysis, Utescu et al. [38] suggested that CKD-related risk factors such as advanced glycation end products may contribute to the accelerated worsening of the cfPWV. Therefore, moderateto-severe CKD may affect the progression of arterial stiffening.

Ankle-Brachial Index

$\mathrm{ABI}<0.90$ is a risk factor for $\mathrm{CV}$ disease and reflects peripheral arterial disease, and $\mathrm{ABI}$ $>1.40$, which is partially related to medial layer calcification, is also a risk factor for CV disease $[7,18]$. In the cross-sectional Cardiovascular Health Study (CHS), Ix et al. [39] reported that CKD was associated with both high and low ABI values. Recently, Garimella et al. [40] have 
Tomiyama and Yamashina: Clinical Considerations for the Association between

Vascular Damage and Chronic Kidney Disease

demonstrated in a 9.8-year follow-up study of MESA $(n=6,814)$ that albuminuria is a risk factor for both high and low $\mathrm{ABI}$ values and that elevated serum cystatin $\mathrm{C}$ is a risk factor for low $\mathrm{ABI}$ values.

In summary, CKD may affect the rate of progression of morphological vascular damage, as assessed by IMT or CACS, even in the early stages, and also serves as an atherogenic factor in the advanced stage of atherosclerosis. However, the effect of CKD on the rate of progression of functional vascular damage, such as arterial stiffening, may be significant in cases with moderate-to-severe CKD.

Can Morphological and Functional Assessments of Vascular Damage be Useful to Predict the Progression of Renal Function Decline?

IMT and CACS

The MESA $(n=4,878)$ reported that increased carotid IMT is a risk factor for the progression of albuminuria [41]. To the best of our knowledge, however, no study has been conducted to examine whether increased IMT and/or a high CACS might be a risk factor for accelerated GFR decline.

\section{Endothelial Function}

For the assessment of endothelial function, FMD and RH-PAT are available in clinical settings. The former assesses endothelial function in the brachial artery, a conduit artery, and the latter assesses endothelial function in the peripheral resistance arteries of the forearm [5, 10]. They are thought to reflect different facets of pathophysiological abnormalities in the endothelium. While the risk factors for CV disease are also risk factors for renal dysfunction [22], controversial results have been reported concerning the significance of the association between endothelial and renal dysfunction. Perticone et al. [42] reported that endothelial dysfunction, as assessed by strain-gauge plethysmography during intra-arterial infusion of acetylcholine, which reflects the endothelial nitric oxide bioavailability in peripheral resistance arteries, was a risk factor for the accelerated renal function decline during at least a 2-year follow-up period in subjects with treated hypertension. On the other hand, in the MESA, Peralta et al. [43] reported that decreased FMD, which reflects the nitric oxid bioavailability in conduit arteries, was not a risk factor for accelerated renal function decline during a 4.8-year follow-up period. Lerman and Zeiher [44] described that endothelial dysfunction was a predictor of CV events, which may occur remotely from the site at which the endothelial dysfunction was initially detected. Further study is needed to clarify whether endothelial dysfunction in the peripheral resistance arteries, rather than in the conduit arteries, might be a better predictor of accelerated renal function decline.

PWV and Wave Reflections/Central Hemodynamics

Differing from other parameters of vascular damage, arterial stiffness is thought to serve as a risk factor for accelerated renal function decline, independent of the conventional risk factors for CV disease, via abnormal central hemodynamics and/or pulsatile nephropathy [5, $12,16]$. Elevated blood pressure is a risk factor for accelerated renal function decline, and conventionally, blood pressure is determined in the brachial artery. As mentioned above, the arterial tree has a blood pressure gradient, and under physiological conditions, the blood pressure is lower at more central sites than at distal sites $[5,12,16]$. When the arterial stiffness increases, the travelling speeds of both the forward and the reflected pressure wave in the arterial tree are increased, and interaction between the two pressure waves is observed at a more proximal site in the arterial tree. This results in a decrease of the pressure gradient in the arterial tree. For the same blood pressure measured in the brachial artery, the blood pressure at the level of the kidney is higher in cases with increased arterial stiffness than in 
Tomiyama and Yamashina: Clinical Considerations for the Association between

Vascular Damage and Chronic Kidney Disease

Table 1. Parameters related to arterial stiffness and renal function decline in prospective studies

\begin{tabular}{|c|c|c|c|c|c|c|}
\hline $\begin{array}{l}\text { First author } \\
\text { [ref.] }\end{array}$ & $\begin{array}{l}\text { Parameter } \\
\text { related to } \\
\text { arterial } \\
\text { stiffness }\end{array}$ & $\begin{array}{l}\text { Parameters of renal } \\
\text { function and outcomes }\end{array}$ & CKD stage & $\begin{array}{l}\text { Study subjects and clinical } \\
\text { characteristics }\end{array}$ & $\begin{array}{l}\text { Follow-up, } \\
\text { years }\end{array}$ & Main findings \\
\hline \multicolumn{7}{|c|}{ Positive results } \\
\hline $\begin{array}{l}\text { Tomiyama } \\
{[35]}\end{array}$ & baPWV & $\begin{array}{l}\text { eGFRcr and proteinuria } \\
\text { (dipstick analysis) } \\
\text { CKD }<60 \mathrm{ml} / \mathrm{min} / 1.73 \mathrm{~m}^{2} \text {, } \\
\text { rapid eGFRcr decline }(2.9 \\
\mathrm{ml} / \mathrm{min} / 1.73 \mathrm{~m}^{2} / \text { year), } \\
\text { incidence of proteinuria }\end{array}$ & $\begin{array}{l}\text { eGFRcr }>60 \mathrm{ml} / \\
\mathrm{min} / 1.73 \mathrm{~m}^{2}\end{array}$ & $\begin{array}{l}\mathrm{n}=2,053 ; \text { mean age }=38 \\
\text { years; } 20 \% \text { women; all } \\
\text { Japanese }\end{array}$ & 5.6 & $\begin{array}{l}\text { baPWV was associated } \\
\text { with the incidence of CKD } \\
\text { and rapid eGFRcr decline, } \\
\text { but not with the incidence } \\
\text { of proteinuria }\end{array}$ \\
\hline $\begin{array}{l}\text { Peralta } \\
{[43]}\end{array}$ & $\begin{array}{l}\text { brPP and } \\
\text { arterial } \\
\text { elasticity } \\
\text { measured by } \\
\text { pulse contour } \\
\text { analysis }\end{array}$ & $\begin{array}{l}\text { eGFRcr and eGFRcys } \\
\text { Changes during the } \\
\text { follow-up period }\end{array}$ & $\begin{array}{l}\text { eGFRcr }>60 \mathrm{ml} / \\
\mathrm{min} / 1.73 \mathrm{~m}^{2}\end{array}$ & $\begin{array}{l}\text { MESA study cohort; } \\
\mathrm{n}=4,853 ; 49 \% \text { women; } \\
\text { 27\% black; } 12 \% \text { Chinese }\end{array}$ & 5 & $\begin{array}{l}\text { brPP and parameters of } \\
\text { arterial elasticity were } \\
\text { associated with eGFR } \\
\text { changes during the } \\
\text { follow-up period }\end{array}$ \\
\hline $\begin{array}{l}\text { Madero } \\
{[46]}\end{array}$ & $\begin{array}{l}\text { cfPWV and } \\
\text { brPP }\end{array}$ & $\begin{array}{l}\text { eGFRcys } \\
\text { CKD }<60 \mathrm{ml} / \mathrm{min} / 1.73 \mathrm{~m}^{2} \text {, } \\
\text { change of eGFRcys during } \\
\text { the follow-up period, rapid } \\
\text { eGFRcys decline }(3 \mathrm{ml} / \\
\left.\text { min } / 1.73 \mathrm{~m}^{2} / \text { year }\right)\end{array}$ & $\begin{array}{l}\text { eGFRcys }>60 \\
\mathrm{ml} / \mathrm{min} / 1.73 \\
\mathrm{~m}^{2}\end{array}$ & $\begin{array}{l}\text { Health, Aging and Body } \\
\text { Composition (Health ABC) } \\
\text { study cohort; } n=2,129 ; \\
\text { mean age = } 74 \text { years; } \\
53 \% \text { female; } 38 \% \text { black }\end{array}$ & $\begin{array}{l}3(n=2,068) \\
\text { and } 10 \\
(n=1,221) \\
\text { Mean }=8.9\end{array}$ & $\begin{array}{l}\text { cfPWV was associated } \\
\text { with the incidence of CKD, } \\
\text { and brPP was associated } \\
\text { with the CKD incidence of } \\
\text { CKD and rapid eGFRcys } \\
\text { decline }\end{array}$ \\
\hline $\begin{array}{l}\mathrm{Kim} \\
{[47]}\end{array}$ & $\begin{array}{l}\text { baPWV, cfPWV, } \\
\text { and brPP }\end{array}$ & $\begin{array}{l}\text { eGFRcr } \\
\text { Rapid eGFRcr decline } \\
\left(3 \mathrm{ml} / \mathrm{min} / 1.73 \mathrm{~m}^{2} / \text { year }\right)\end{array}$ & $\begin{array}{l}\text { eGFRcr }>30 \mathrm{ml} / \\
\mathrm{min} / 1.73 \mathrm{~m}^{2} \\
(100 / 913 \\
\text { subjects had } \\
\text { eGFRcr } 30-59)\end{array}$ & $\begin{array}{l}\mathrm{n}=913 ; \text { mean age }=63 \\
\text { years; } 45 \% \text { women }\end{array}$ & 3.2 & $\begin{array}{l}\text { brPP, but not cfPWV and } \\
\text { baPWV, was associated } \\
\text { with rapid renal function } \\
\text { decline }\end{array}$ \\
\hline $\begin{array}{l}\text { Chen } \\
{[48]}\end{array}$ & baPWV & $\begin{array}{l}\text { eGFRcr } \\
\text { eGFR slope calculated from } \\
\text { more than } 3 \text { measurements } \\
\text { of eGFRcr }\end{array}$ & CKD stages 3-5 & $\begin{array}{l}\mathrm{n}=145 ; \text { mean age }=69 \\
\text { years; } 32 \% \text { women; all } \\
\text { Chinese }\end{array}$ & 1.1 & $\begin{array}{l}\text { baPWV was associated } \\
\text { with the eGFR slope }\end{array}$ \\
\hline $\begin{array}{l}\text { Ford } \\
{[49]}\end{array}$ & $\begin{array}{l}\text { cfPWV and } \\
\text { brPP }\end{array}$ & $\begin{array}{l}\text { eGFRcr } \\
\text { Gradient of reciprocal } \\
\text { creatinine plots and renal } \\
\text { end point (dialysis/25\% } \\
\text { decline of eGFRcr) }\end{array}$ & $\begin{array}{l}\text { CKD stages } 3 \\
\text { and } 4\end{array}$ & $\begin{array}{l}n=133 ; \text { mean age }=69 \\
\text { years; } 22 \% \text { women }\end{array}$ & 1.5 & $\begin{array}{l}\text { cfPWV was associated } \\
\text { with renal function decline } \\
\text { and the renal end point }\end{array}$ \\
\hline $\begin{array}{l}\text { Briet } \\
{[50]}\end{array}$ & $\begin{array}{l}\text { cfPWV and AI/ } \\
\text { cPP obtained } \\
\text { from carotid } \\
\text { artery. }\end{array}$ & $\begin{array}{l}\text { GFR determined by } \\
{ }^{51} \text { Cr-EDTA } \\
\text { GFR slope and end-stage } \\
\text { renal disease (dialysis or } \\
\text { kidney transplantation) }\end{array}$ & $\begin{array}{l}\text { CKD (mean } \\
\text { GFR } 32 \mathrm{ml} / \\
\mathrm{min} / 1.73 \mathrm{~m}^{2} \text { ) }\end{array}$ & $\begin{array}{l}\mathrm{n}=180 ; \text { mean age }=60 \\
\text { years; } 26 \% \text { women }\end{array}$ & 3.1 & $\begin{array}{l}\text { Carotid PP, but not cfPWV, } \\
\text { was associated with the } \\
\text { incidence of end-stage } \\
\text { renal disease }\end{array}$ \\
\hline $\begin{array}{l}\text { Munakata } \\
{[51]}\end{array}$ & baPWV & $\begin{array}{l}\text { Microalbuminuria = urinary } \\
\text { albumin/creatinine } \\
\text { excretion ratio }>30\end{array}$ & $\begin{array}{l}\text { Mean serum } \\
\text { creatinine } 0.7 \\
\mathrm{mg} / \mathrm{dl}\end{array}$ & $\begin{array}{l}\mathrm{n}=321 ; \text { mean age }=62 \\
\text { years; } 61 \% \text { women }\end{array}$ & 2 & $\begin{array}{l}\text { baPWV was associated } \\
\text { with the incidence of } \\
\text { microalbuminuria }\end{array}$ \\
\hline \multicolumn{7}{|c|}{ Negative results } \\
\hline $\begin{array}{l}\text { Tomiyama } \\
{[52]}\end{array}$ & $\begin{array}{l}\text { baPWV, rAI, } \\
\text { brPP and PP2 }\end{array}$ & $\begin{array}{l}\text { eGFRcr and eGFRcys } \\
\text { Changes during the } \\
\text { follow-up period }\end{array}$ & $\begin{array}{l}\text { eGFRcr }>60 \mathrm{ml} / \\
\min / 1.73 \mathrm{~m}^{2}\end{array}$ & $\begin{array}{l}\mathrm{n}=1,229 ; \text { mean age }=43 \\
\text { years; all Japanese men } \\
\text { without hypertension }\end{array}$ & 3 & $\begin{array}{l}\text { None of the parameters of } \\
\text { arterial stiffness/central } \\
\text { hemodynamics was } \\
\text { associated with the } \\
\text { changes in renal function }\end{array}$ \\
\hline $\begin{array}{l}\text { Upadhyay } \\
\text { [53] }\end{array}$ & $\begin{array}{l}\text { cfPWV and AI/ } \\
\text { cPP obtained } \\
\text { from carotid } \\
\text { artery }\end{array}$ & $\begin{array}{l}\text { eGFRcr, eGFRcys, and } \\
\text { urinary albumin/creatinine } \\
\text { excretion ratio } \\
\mathrm{CKD}<60 \mathrm{ml} / \mathrm{min} / 1.73 \mathrm{~m}^{2}, \\
\text { microalbuminuria }=\text { urinary } \\
\text { albumin/creatinine } \\
\text { excretion ratio }>17 \text { in men } \\
\text { and } 25 \text { in women }\end{array}$ & $\begin{array}{l}\mathrm{eGFR}>60 \mathrm{ml} / \\
\mathrm{min} / 1.73 \mathrm{~m}^{2}\end{array}$ & $\begin{array}{l}\text { Framingham study cohort; } \\
\mathrm{n}=2,501 \text { for CKD; } \\
\mathrm{n}=5,339 \text { for } \\
\text { microalbuminuria; } \\
\text { Subjects without CKD: } \\
\text { mean age = } 60 \text { years; } \\
\text { 55\% women } \\
\text { Subjects without } \\
\text { microalbuminuria: mean } \\
\text { age = 46 years; } \\
\text { 54\% women }\end{array}$ & $7-10$ & $\begin{array}{l}\text { None of the parameters of } \\
\text { arterial stiffness/central } \\
\text { hemodynamics was } \\
\text { associated with the } \\
\text { incidence of CKD and/or } \\
\text { microabluminuria }\end{array}$ \\
\hline
\end{tabular}

brPP = Brachial pulse pressure; eGFRcr = estimated glomerular filtration rate from the serum creatinine; eGFRcys = estimated glomerular filtration rate pressure obtained from the second peak of the radial pressure waveform; $\mathrm{AI}=$ augmentation index; $\mathrm{cPP}=$ central pulse pressure.

those without increased arterial stiffness, and the renal function may decline more rapidly in the former cases $[5,12,16]$. Conventionally, blood pressure is measured in $\mathrm{mm} \mathrm{Hg}$, and the specific gravity of mercury is 13 . Therefore, a blood pressure of $140 \mathrm{~mm} \mathrm{Hg}$ would correspond to the energy that can push up water up to a height of $180 \mathrm{~cm}$. Thus, the heart generates 
Tomiyama and Yamashina: Clinical Considerations for the Association between

Vascular Damage and Chronic Kidney Disease

a large amount of energy during in every cardiac contraction, which is mostly absorbed in the aorta by its shock absorber effect. However, increased aortic stiffness attenuates this cushioning effect and increases the transmission of the pulsatile energy generated in the heart to the peripheral microcirculation. These phenomena cause the condition referred to as pulsatile nephropathy that results in accelerated renal function decline $[5,12,16,45]$. Based on these logical backgrounds, several prospective studies have been conducted to examine whether increased arterial stiffness might be a risk factor for accelerated renal function decline [35, 46-53]. The results of these studies are summarized in table 1. Most studies demonstrated that parameters related to arterial stiffness and/or wave reflection/central hemodynamics are useful to predict the rate of renal function decline.

Ankle-Brachial Index

The Atherosclerosis Risk in Communities (ARIC) study [54] and the Framingham study [55] demonstrated that a low ABI represents a risk factor for accelerated renal function decline. Foster et al. [55] describe two plausible mechanisms for this association: (1) subjects with a low ABI may have subclinical vascular damage in the renal arterial bed, which cannot be detected by GFR and/or microalbiminuria, and (2) they might also have the shared risk factors or preexisting systemic disease that could lead to both peripheral vascular damage and decreased renal function.

In summary, both vascular morphological and functional abnormalities are risk factors for the progression of renal dysfunction. Arterial stiffness/central hemodynamics are thought to serve as a risk factor for accelerated renal function decline, independent of the conventional risk factors for CV disease.

\section{Conclusion}

A vicious cycle may exist between renal dysfunction and atherogenic states even from their early stages. Vascular function abnormalities associated with atherosclerosis may accelerate this cycle. Not only renal but also vascular assessment, especially measurements of arterial stiffness markers and/or wave reflection/central hemodynamics, is needed to evaluate the progression of this vicious cycle. As the next step, we propose to examine whether improvement of vascular function abnormalities, especially arterial destiffening, can interrupt this vicious cycle.

\section{References}

1 Fox CS, Matsushita K, Woodward M, Bilo HJ, Chalmers J, Heerspink HJ, Lee BJ, Perkins RM, Rossing P, Sairenchi T, Tonelli M, Vassalotti JA, Yamagishi K, Coresh J, de Jong PE, Wen CP, Nelson RG; Chronic Kidney Disease Prognosis Consortium: Associations of kidney disease measures with mortality and end-stage renal disease in individuals with and without diabetes: a meta-analysis. Lancet 2012;380:1662-1673.

2 Mahmoodi BK, Matsushita K, Woodward M, Blankestijn PJ, Cirillo M, Ohkubo T, Rossing P, Sarnak MJ, Stengel B, Yamagishi K, Yamashita K, Zhang L,Coresh J, de Jong PE, Astor BC; Chronic Kidney Disease Prognosis Consortium: Associations of kidney disease measures with mortality and end-stage renal disease in individuals with and without hypertension: a meta-analysis. Lancet 2012;380:1649-1661.

3 Hatamizadeh P, Fonarow GC, Budoff MJ, Darabian S, Kovesdy CP, Kalantar-Zadeh K: Cardiorenal syndrome: pathophysiology and potential targets for clinical management. Nat Rev Nephrol 2013;9:99-111.

4 Ronco C, Ronco F: Cardio-renal syndromes: a systematic approach for consensus definition and classification. Heart Fail Rev 2012;17:151-160.

5 Tomiyama H, Yamashina A: Non-invasive vascular function tests: their pathophysiological background and clinical application. Circ J 2010;74:24-33. 
Tomiyama and Yamashina: Clinical Considerations for the Association between

Vascular Damage and Chronic Kidney Disease

6 Roman MJ, Naqvi TZ, Gardin JM, Gerhard-Herman M, Jaff M, Mohler E; American Society of Echocardiography; Society for Vascular Medicine and Biology: American society of echocardiography report. Clinical application of noninvasive vascularultrasound in cardiovascular risk stratification: a report from the American Society of Echocardiography and the Society for Vascular Medicine and Biology. Vasc Med 2006;11:201-211.

7 Greenland P, Alpert JS, Beller GA, Benjamin EJ, Budoff MJ, Fayad ZA, Foster E, Hlatky MA, Hodgson JM, Kushner FG, Lauer MS, Shaw LJ, Smith SC Jr, Taylor AJ, Weintraub WS, Wenger NK, Jacobs AK; American College of Cardiology Foundation/American Heart Association Task Force on Practice Guidelines: 2010 ACCF/AHA guideline for assessment of cardiovascular risk in asymptomatic adults: a report of the American College of Cardiology Foundation/American Heart Association Task Force on Practice Guidelines. Circulation 2010; 122:e584-e636.

8 Engelen L, Ferreira I, Stehouwer CD, Boutouyrie P, Laurent S; Reference Values for Arterial Measurements Collaboration: Reference intervals for common carotid intima-media thickness measured with echotracking: relation with risk factors. Eur Heart J 2013;34:2368-2380.

9 Nucifora G, Bax JJ, van Werkhoven JM, Boogers MJ, Schuijf JD: Coronary artery calcium scoring in cardiovascular risk assessment. Cardiovasc Ther 2011;29:e43-e53.

10 Yeboah J, McClelland RL, Polonsky TS, Burke GL, Sibley CT, O’Leary D, Carr JJ, Goff DC, Greenland P, Herrington DM: Comparison of novel risk markers for improvement in cardiovascular risk assessment in intermediaterisk individuals. JAMA 2012;308:788-795.

11 Flammer AJ, Anderson T, Celermajer DS, Creager MA, Deanfield J, Ganz P, Hamburg NM, Lüscher TF, Shechter M, Taddei S, Vita JA, Lerman A: The assessment of endothelial function: from research into clinical practice. Circulation 2012;126:753-767.

12 DeLoach SS, Townsend RR: Vascular stiffness: its measurement and significance for epidemiologic and outcome studies. Clin J Am Soc Nephrol 2008;3:184-192.

13 Van Bortel LM, Laurent S, Boutouyrie P, Chowienczyk P, Cruickshank JK, De Backer T, Filipovsky J, Huybrechts S, Mattace-Raso FU, Protogerou AD, Schillaci G, Segers P, Vermeersch S, Weber T; Artery Society; European Society of Hypertension Working Group on Vascular Structure and Function; European Network for Noninvasive Investigation of Large Arteries: Expert consensus document on the measurement of aortic stiffness in daily practice using carotid-femoral pulse wave velocity. J Hypertens 2012;30:445-448.

14 Motobe K, Tomiyama H, Koji Y, Yambe M, Gulinisa Z, Arai T, Ichihashi H, Nagae T, Ishimaru S, Yamashina A: Cut-off value of the ankle-brachial pressure index at which the accuracy of brachial-ankle pulse wave velocity measurement is diminished. Circ J 2005;69:55-60.

15 Tanaka H, Munakata M, Kawano Y, Ohishi M, Shoji T, Sugawara J, Tomiyama H, Yamashina A, Yasuda H, Sawayama T, Ozawa T: Comparison between carotid-femoral and brachial-ankle pulse wave velocity as measures of arterial stiffness. J Hypertens 2009;27:2022-2027.

16 O’Rourke MF, Hashimoto J: Mechanical factors in arterial aging: a clinical perspective. J Am Coll Cardiol 2007; 50:1-13.

17 Wohlfahrt P, Krajcoviechová A, Seidlerová J, Mayer O, Filipovsky J, Cífková R: Comparison of noninvasive assessments of central blood pressure using general transfer function and late systolic shoulder of the radial pressure wave. Am J Hypertens 2014;27:162-168.

18 Lin JS, Olson CM, Johnson ES, Whitlock EP: The ankle-brachial index for peripheral artery disease screening and cardiovascular disease prediction among asymptomatic adults: a systematic evidence review for the U.S. Preventive ServicesTask Force. Ann Intern Med 2013;159:333-341.

19 Koji Y, Tomiyama H, Ichihashi H, Nagae T, Tanaka N, Takazawa K, Ishimaru S, Yamashina A: Comparison of ankle-brachial pressure index and pulse wave velocity as markers of the presence of coronary artery disease in subjects with a high risk of atherosclerotic cardiovascular disease. Am J Cardiol 2004;94:868-872.

20 Carter SA: Indirect systolic pressure and pulse waves in arterial occlusive diseases of the lower extremities. Circulation 1968;37:624-637.

21 Ankle Brachial Index Collaboration; Fowkes FG, Murray GD, Butcher I, et al: Ankle brachial index combined with Framingham Risk Score to predict cardiovascular events and mortality: a meta-analysis. JAMA 2008;300: 197-208.

22 Drüeke TB, Massy ZA: Atherosclerosis in CKD: differences from the general population. Nat Rev Nephrol 2010; 6:723-735.

23 Zhang L, Zhao F, Yang Y, Qi L, Zhang B, Wang F, Wang S, Liu L, Wang H: Association between carotid artery intima-media thickness and early-stage CKD in a Chinese population. Am J Kidney Dis 2007;49:786-792.

24 Ohara T, Kokubo Y, Toyoda K, Watanabe M, Koga M, Nakamura S, Nagatsuka K, Minematsu K, Nakagawa M, Miyamoto Y: Impact of chronic kidney disease on carotid atherosclerosis according to blood pressure category: the Suita study. Stroke 2013;44:3537-3539.

25 Desbien AM, Chonchol M, Gnahn H, Sander D: Kidney function and progression of carotid intima-media thickness in a community study. Am J Kidney Dis 2008;51:584-593.

26 Yilmaz MI, Qureshi AR, Carrero JJ, Saglam M, Suliman ME, Caglar K, Eyileten T, Sonmez A, Oguz Y, Vural A, Yenicesu M, Axelsson J: Predictors of carotid artery intima-media thickness in chronic kidney disease and kidney transplant patients without overt cardiovascular disease. Am J Nephrol 2010;31:214-221.

27 Budoff MJ, Rader DJ, Reilly MP, Mohler ER 3rd, Lash J, Yang W, Rosen L, Glenn M, Teal V, Feldman HI; CRIC Study Investigators: Relationship of estimated GFR and coronary artery calcification in the CRIC (Chronic Renal Insufficiency Cohort) Study. Am J Kidney Dis 2011;58:519-526. 
Tomiyama and Yamashina: Clinical Considerations for the Association between

Vascular Damage and Chronic Kidney Disease

28 Lamprea-Montealegre JA, McClelland RL, Astor BC, Matsushita K, Shlipak M, de Boer IH, Szklo M: Chronic kidney disease, plasma lipoproteins, and coronary artery calcium incidence: the Multi-Ethnic Study of Atherosclerosis. Arterioscler Thromb Vasc Biol 2013;33:652-658.

29 Tuttle KR, Short RA: Longitudinal relationships among coronary artery calcification, serum phosphorus, and kidney function. Clin J Am Soc Nephrol 2009;4:1968-1973.

30 Yilmaz MI, Stenvinkel P, Sonmez A, Saglam M, Yaman H, Kilic S, Eyileten T, Caglar K, Oguz Y, Vural A, Çakar M, Altun B, Yenicesu M, Carrero JJ: Vascular health, systemic inflammation and progressive reduction in kidney function; clinical determinants and impact on cardiovascular outcomes. Nephrol Dial Transplant 2011;26: 3537-3543.

31 Lilitkarntakul P, Dhaun N, Melville V, Blackwell S, Talwar DK, Liebman B, Asai T, Pollock J, Goddard J, Webb DJ: Blood pressure and not uraemia is the major determinant of arterial stiffness and endothelial dysfunction in patients with chronic kidney disease and minimal co-morbidity. Atherosclerosis 2011;216: 217-225.

32 Moody WE, Edwards NC, Madhani M, Chue CD, Steeds RP, Ferro CJ, Townend JN: Endothelial dysfunction and cardiovascular disease in early-stage chronic kidney disease: cause or association? Atherosclerosis 2012;223: 86-94.

33 Yoshida M, Tomiyama H, Yamada J, Koji Y, Shiina K, Nagata M, Yamashina A: Relationships among renal function loss within the normal to mildly impaired range, arterial stiffness, inflammation, and oxidative stress. Clin J Am Soc Nephrol 2007;2:1118-1124.

34 Hermans MM, Henry R, Dekker JM, Kooman JP, Kostense PJ, Nijpels G, Heine RJ, Stehouwer CD: Estimated glomerular filtration rate and urinary albumin excretion are independently associated with greater arterial stiffness: the Hoorn Study. J Am Soc Nephrol 2007;18:1942-1952.

35 Tomiyama H, Tanaka H, Hashimoto H, Matsumoto C, Odaira M, Yamada J, Yoshida M, Shiina K, Nagata M, Yamashina A: Arterial stiffness and declines in individuals with normal renal function/early chronic kidney disease. Atherosclerosis 2010;212:345-350.

36 Tholen S, Klofat K, Pan CR, Schmaderer C, Lutz J, Heemann U, Baumann M: Progression of aortic pulse wave velocity in patients with chronic kidney disease. J Clin Hypertens (Greenwich) 2013;15:833-838.

37 Benetos A, Adamopoulos C, Bureau JM, Temmar M, Labat C, Bean K, Thomas F, Pannier B, Asmar R, Zureik M, Safar M, Guize L: Determinants of accelerated progression of arterial stiffness in normotensive subjects and in treated hypertensive subjects over a 6-year period. Circulation 2002;105:1202-1207.

38 Utescu MS, Couture V, Mac-Way F, De Serres SA, Marquis K, Larivière R, Desmeules S, Lebel M, Boutouyrie P, Agharazii M: Determinants of progression of aortic stiffness in hemodialysis patients: a prospective longitudinal study. Hypertension 2013;62:154-160.

39 Ix JH, Katz R, De Boer IH, Kestenbaum BR, Allison MA, Siscovick DS, Newman AB, Sarnak MJ, Shlipak MG, Criqui MH: Association of chronic kidney disease with the spectrum of ankle brachial index the CHS (Cardiovascular Health Study). J Am Coll Cardiol 2009;54:1176-1184.

40 Garimella PS, Ix JH, Katz R, Shlipak MG, Criqui MH, Siscovick DS, Kramer H, Sibley CT, Sarnak MJ: Association of albumin-creatinine ratio and cystatin $C$ with change in ankle-brachial index: the Multi-Ethnic Study of Atherosclerosis (MESA). Am J Kidney Dis 2015;65:33-40.

41 Yu Z, Schneck M, Jacobs DR Jr, Liu K, Allison M, O'Leary D, Durazo R, Darwin C, Kramer H: Association of carotid intima-media thickness with progression of urine albumin-creatinine ratios in the Multi-Ethnic Study of Atherosclerosis (MESA). Am J Kidney Dis 2011;57:62-70.

42 Perticone F, Maio R, Perticone M, Sciacqua A, Shehaj E, Naccarato P, Sesti G: Endothelial dysfunction and subsequent decline in glomerular filtration rate in hypertensive patients. Circulation 2010;122:379-384.

43 Peralta CA, Jacobs DR Jr, Katz R, Ix JH, Madero M, Duprez DA, Sarnak MJ, Criqui MH, Kramer HJ, Palmas W, Herrington D, Shlipak MG: Association of pulse pressure, arterial elasticity, and endothelial function with kidney function decline among adults with estimated GFR $>60 \mathrm{ml} / \mathrm{min} / 1.73 \mathrm{~m}^{2}$ : the Multi-Ethnic Study of Atherosclerosis (MESA). Am J Kidney Dis 2012;59:41-49.

44 Lerman A, Zeiher AM: Endothelial function: cardiac events. Circulation 2005;111:363-368.

45 O'Rourke MF, Safar ME, Dzau V: The Cardiovascular Continuum extended: aging effects on the aorta and microvasculature. Vasc Med 2010;15:461-468.

46 Madero M, Peralta C, Katz R, Canada R, Fried L, Najjar S, Shlipak M, Simonsick E, Lakatta E, Patel K, Rifkin D, Hawkins M, Newman A, Sarnak M; Health ABC Study: Association of arterial rigidity with incident kidney disease and kidney function decline: the Health ABC study. Clin J Am Soc Nephrol 2013;8:424-433.

47 Kim CS, Kim HY, Kang YU, Choi JS, Bae EH, Ma SK, Kim SW: Association of pulse wave velocity and pulse pressure with decline in kidney function. J Clin Hypertens (Greenwich) 2014;16:372-377.

48 Chen SC, Chang JM, Liu WC, Tsai YC, Tsai JC, Hsu PC, Lin TH, Lin MY, Su HM, Hwang SJ, Chen HC: Brachial-ankle pulse wave velocity and rate of renal function decline and mortality in chronic kidney disease. Clin J Am Soc Nephrol 2011;6:724-732.

49 Ford ML, Tomlinson LA, Chapman TP, Rajkumar C, Holt SG: Aortic stiffness is independently associated with rate of renal function decline in chronic kidney disease stages 3 and 4. Hypertension 2010;55:11101115.

50 Briet M, Collin C, Karras A, Laurent S, Bozec E, Jacquot C, Stengel B, Houillier P, Froissart M, Boutouyrie P; Nephrotest Study Group: Arterial remodeling associates with CKD progression. J Am Soc Nephrol 2011;22: 967-974. 
51 Munakata M, Miura Y, Yoshinaga K; J-TOPP study group: Higher brachial-ankle pulse wave velocity as an independent risk factor for future microalbuminuria in patients with essential hypertension: the J-TOPP study. J Hypertens 2009;27:1466-1471.

52 Tomiyama H, Townsend RR, Matsumoto C, Kimura K, Odaira M, Yoshida M, Shiina K, Yamashina A: Arterial stiffness/central hemodynamics, renal function, and development of hypertension over the short term. J Hypertens 2014;32:90-99.

53 Upadhyay A, Hwang SJ, Mitchell GF, Vasan RS, Vita JA, Stantchev PI, Meigs JB, Larson MG, Levy D, Benjamin EJ, Fox CS: Arterial stiffness in mild-to-moderate CKD. J Am Soc Nephrol 2009;20:2044-2053.

54 O'Hare AM, Rodriguez RA, Bacchetti P: Low ankle-brachial index associated with rise in creatinine level over time: results from the atherosclerosis risk in communities study. Arch Intern Med 2005;165:1481-1485.

55 Foster MC, Ghuman N, Hwang SJ, Murabito JM, Fox CS: Low ankle-brachial index and the development of rapid estimated GFR decline and CKD. Am J Kidney Dis 2013;61:204-210. 